\title{
The inhibition of fat cell proliferation by $n-3$ fatty acids in dietary obese mice
}

\author{
Michal Hensler ${ }^{1}$, Kristina Bardova', Zuzana Macek Jilkova ${ }^{1}$, Walter Wahli ${ }^{2}$, Daniel Meztger ${ }^{3}$, Pierre Chambon ${ }^{3}$, \\ Jan Kopecky ${ }^{1}$ and Pavel Flachs ${ }^{1 *}$
}

\begin{abstract}
Background: Long-chain n-3 polyunsaturated fatty acids (LC n-3 PUFA) of marine origin exert multiple beneficial effects on health. Our previous study in mice showed that reduction of adiposity by LC n-3 PUFA was associated with both, a shift in adipose tissue metabolism and a decrease in tissue cellularity. The aim of this study was to further characterize the effects of LC n-3 PUFA on fat cell proliferation and differentiation in obese mice.

Methods: A model of inducible and reversible lipoatrophy (aP2-Cre-ER ${ }^{T 2}$ PPAR $\gamma^{\mathrm{L} 2 / L 2}$ mice) was used, in which the death of mature adipocytes could be achieved by a selective ablation of peroxisome proliferator-activated receptor $\gamma$ in response to i.p. injection of tamoxifen. Before the injection, obesity was induced in male mice by 8-weekfeeding a corn oil-based high-fat diet (CHF) and, subsequently, mice were randomly assigned (day 0 ) to one of the following groups: (i) mice injected by corn-oil-vehicle only, i.e."control" mice, and fed cHF; (ii) mice injected by tamoxifen in corn oil, i.e. "mutant" mice, fed CHF; (iii) control mice fed cHF diet with15\% of dietary lipids replaced by LC $n-3$ PUFA concentrate ( $\mathrm{CHF}+\mathrm{F})$; and (iv) mutant mice fed $\mathrm{cHF}+\mathrm{F}$. Blood and tissue samples were collected at days 14 and 42.
\end{abstract}

Results: Mutant mice achieved a maximum weight loss within 10 days post-injection, followed by a compensatory body weight gain, which was significantly faster in the $\mathrm{cHF}$ as compared with the $\mathrm{CHF}+\mathrm{F}$ mutant mice. Also in control mice, body weight gain was depressed in response to dietary LC $n-3$ PUFA. At day 42 , body weights in all groups stabilized, with no significant differences in adipocyte size between the groups, although body weight and adiposity was lower in the $\mathrm{CHF}+\mathrm{F}$ as compared with the $\mathrm{CHF}$ mice, with a stronger effect in the mutant than in control mice. Gene expression analysis documented depression of adipocyte maturation during the reconstitution of adipose tissue in the $\mathrm{CHF}+\mathrm{F}$ mutant mice.

Conclusion: Dietary LC n-3 PUFA could reduce both hypertrophy and hyperplasia of fat cells in vivo. Results are in agreement with the involvement of fat cell turnover in control of adiposity.

Keywords: DHA and EPA, fish oil, fat cell turnover

\section{Background}

Adipose tissue and its secreted products, adipokines, have a major role in the development of obesity-associated metabolic disarrangement including dyslipidaemia and insulin resistance (i.e. the components of metabolic syndrome). Long-chain $n-3$ polyunsaturated fatty acids (LC $n-3$ PUFA), namely eicosapentaenoic acid (EPA; 20:5 n-3) and docosahexaenoic acid (DHA; 22:6 n-3) act

\footnotetext{
* Correspondence: flachs@biomed.cas.cz

'Department of Adipose Tissue Biology, Institute of Physiology Academy of

Sciences of the Czech Republic v.vi.., Prague, Czech Republic Full list of author information is available at the end of the article
}

as natural hypolipidemics, reduce risk of cardiovascular disease and could prevent development of obesity and insulin resistance in humans [1]. Also our experiments on mice have demonstrated that substitution of $15 \%$ lipids in a corn oil-based high fat diet (cHF) by LC $n-3$ PUFA concentrate (i.e. feeding $\mathrm{cHF}+\mathrm{F}$ diet, see Methods) prevented dietary induced obesity and associated metabolic disorders [2-4]. The preferential decrease in abdominal adipose tissue growth resulted not only from modulation of metabolism in response to LC $n-3$ PUFA [5], but probably also in part from the inhibition of fat cell proliferation. Quantification of adipose tissue DNA
C Biomed Central 
revealed that the reduction of epididymal fat was associated with 34-50\% depression of tissue cellularity [2]. In vitro, both EPA and DHA inhibited adipocyte differentiation and lipid droplet formation [6-8] and DHA induced apoptosis in postconfluent preadipocytes [7]. To further characterize inhibitory effect of LC $n-3$ PUFA on adipose cell proliferation and differentiation in vivo, and to learn more about the role of fat cell turnover in the control of adiposity [9], we used mouse transgenic model of inducible and reversible lipoatrophy (aP2-Cre-ER ${ }^{\mathrm{T} 2}$ PPAR $\left.\gamma^{\mathrm{L} 2 / \mathrm{L} 2}\right)$. In this model, death of mature brown and white adipocytes is achieved by selective ablation of peroxisome proliferator-activated receptor $\gamma(\mathrm{PPAR} \gamma)$ using the tamoxifen-dependent $\mathrm{Cre}-\mathrm{ER}^{\mathrm{T} 2}$ recombination system [10]. PPAR $\gamma$ is essential for survival of mature adipocyte and deletion of PPAR $\gamma$ causes adipocyte death, triggers an inflammatory reaction and promotes proliferation and differentiation of preadipocytes into new adipocyte expressing PPAR $\gamma$ [10]. Our results document that LC $n-3$ PUFA slow down compensatory adipose tissue growth and adipocyte proliferation after the transgenically-induced transient lipoatrophy and they also support the notion [9] that fat cell turnover is involved in the control of adipose tissue mass.

\section{Methods}

\section{Animals and experimental design}

Adipose tissue specific PPAR $\gamma$ conditional knock out mice (aP2-Cre-ER ${ }^{\mathrm{T} 2}$ PPAR $\gamma^{\mathrm{L} 2 / \mathrm{L} 2}$ ) were used [10]. In this transgenic model, PPAR $\gamma$ can be selectively ablated in mature adipocytes by the conditional Cre-ER ${ }^{\mathrm{T} 2} \mathrm{Cre}$ recombinase whose activity depends on tamoxifen administration [10]. At 4 weeks of age, male mice were weaned onto a standard laboratory chow (Chow; lipid content $\sim 3.4 \% \mathrm{wt} / \mathrm{wt}$; extruded R/M-H diet; Ssniff Spezialdiäten, Soest, Germany) and maintained at $22^{\circ} \mathrm{C}$ on a $12 \mathrm{~h}$ light-dark cycle with free access to food and water. Starting at 3 months of age, mice were fed a corn oil based high-fat diet (cHF; lipid content $\sim 35 \% \mathrm{wt} / \mathrm{wt}$ ), and at 5 months of age (day 0; see Figure 1) the animals were randomly assigned to one of the following groups: (i) premutant aP2-Cre-ER ${ }^{\mathrm{T} 2} \mathrm{PPAR} \gamma^{\mathrm{L} 2 / \mathrm{L} 2}$ mice, intraperitoneally twice injected by $100 \mu \mathrm{l}$ of corn oil at day 0 and day 1, hereafter named control PPAR $\boldsymbol{\gamma}^{\text {ad+l+ }}$ mice, which were fed cHF diet; (ii) aP2-Cre-ER ${ }^{\mathrm{T} 2} \mathrm{PPAR} \gamma^{\mathrm{L}-/ \mathrm{L}-}$ mice intraperitoneally twice injected by $1 \mathrm{mg}$ tamoxifen in $100 \mu \mathrm{l}$ of corn oil at day 0 and day 1 , and hereafter named mutant PPAR $\boldsymbol{\gamma}^{\text {ad-/- }}$ mice, which were fed $\mathrm{cHF}$ diet; (iii) control PPAR $\gamma^{\text {ad+/+ }}$ mice fed cHF diet supplemented with LC $n$-3 PUFA concentrate (product EPAX 1050 TG (46\% DHA, 14\% EPA), EPAX, a.s., Aalesund, Norway) replacing $15 \%$ of dietary lipids $(\mathrm{cHF}+\mathrm{F}$ diet); and (iv) mutant PPAR $\gamma^{\text {ad-/- }}$ mice fed $c H F+F$ diet.
Samples were collected for various analyses at day 14 and at day 42. Fresh rations of food were distributed every second day, food consumption and body weights were recorded. Mice were sacrificed by cervical dislocation in random fed state (between 8 a.m. and 10 a.m.), and EDTA-plasma and selected tissues were collected for various analyses. Several independent experiments were performed, in accordance with the guidelines of the Institute of Physiology for the use and care of laboratory animals.

\section{Histological analysis of adipose tissue}

Epididymal white fat samples were fixed in $4 \%$ formaldehyde embedded in paraffin and stained with hematoxylin/eosin. Morphometry of adipocytes was performed as before [11], using NIS-Elements 3.0 AR morphometric software (Laboratory Imaging, Prague, Czech Republic). The morphometry data are based on more than 800 cells taken randomly from six different areas per animal.

\section{Quantitative real time PCR}

Total RNA isolated using TRI Reagent (Molecular Research Center, Inc, Cincinnati, OH, USA). Levels of various transcripts were evaluated using LightCycler 480 II instrument (Roche Diagnostic Ltd., Rotkreuz, Switzerland) and LightCycler 480 SYBR Green I Master kit (Roche Diagnostic Ltd., Mannheim, Germany). PCR condition were $95^{\circ} \mathrm{C}$ for $5 \mathrm{~min}$ and 45 cycles of $95^{\circ} \mathrm{C}$ for $10 \mathrm{~s}, 55-60^{\circ} \mathrm{C}$ for $10 \mathrm{~s}$ and $72^{\circ} \mathrm{C}$ for $20 \mathrm{~s}$. Specificity of the amplified PCR product was assessed by performing a melting curve analysis. Lasergene 7 software (DNASTAR, Inc. Madison, WI, USA) was used to design primers. The PCR primer pairs were used as in Table 1. To correct for intersample variation, levels of the transcript were normalized using geometrical mean of two reference genes.

\section{Plasma adiponectin}

Adiponectin levels were determined using Western blotting as before [11]. Tris-acetate gradient gel (NuPAGE 3-8\%, Invitrogen, Life Technologies, Carlsbad, CA, USA) was used for division of multimeric forms of adiponectin in plasma. Primary rabbit anti-mouse polyclonal antibodies (BioVendor, Brno, Czech Republic), followed by secondary donkey anti-rabbit IgG infrared dye conjugated antibodies (IR Dye 800, Rockland, Gilbertsville, PA, USA) were using. Membranes were scanned using Odyssey IR imager (Li-Cor Biosciences, Lincoln, NE, USA).

\section{Statistical analysis}

All values are presented as mean \pm SE. Logarithmic transformation was used to stabilize variance in cells when necessary. Data were analyzed by one-way 


\section{A}

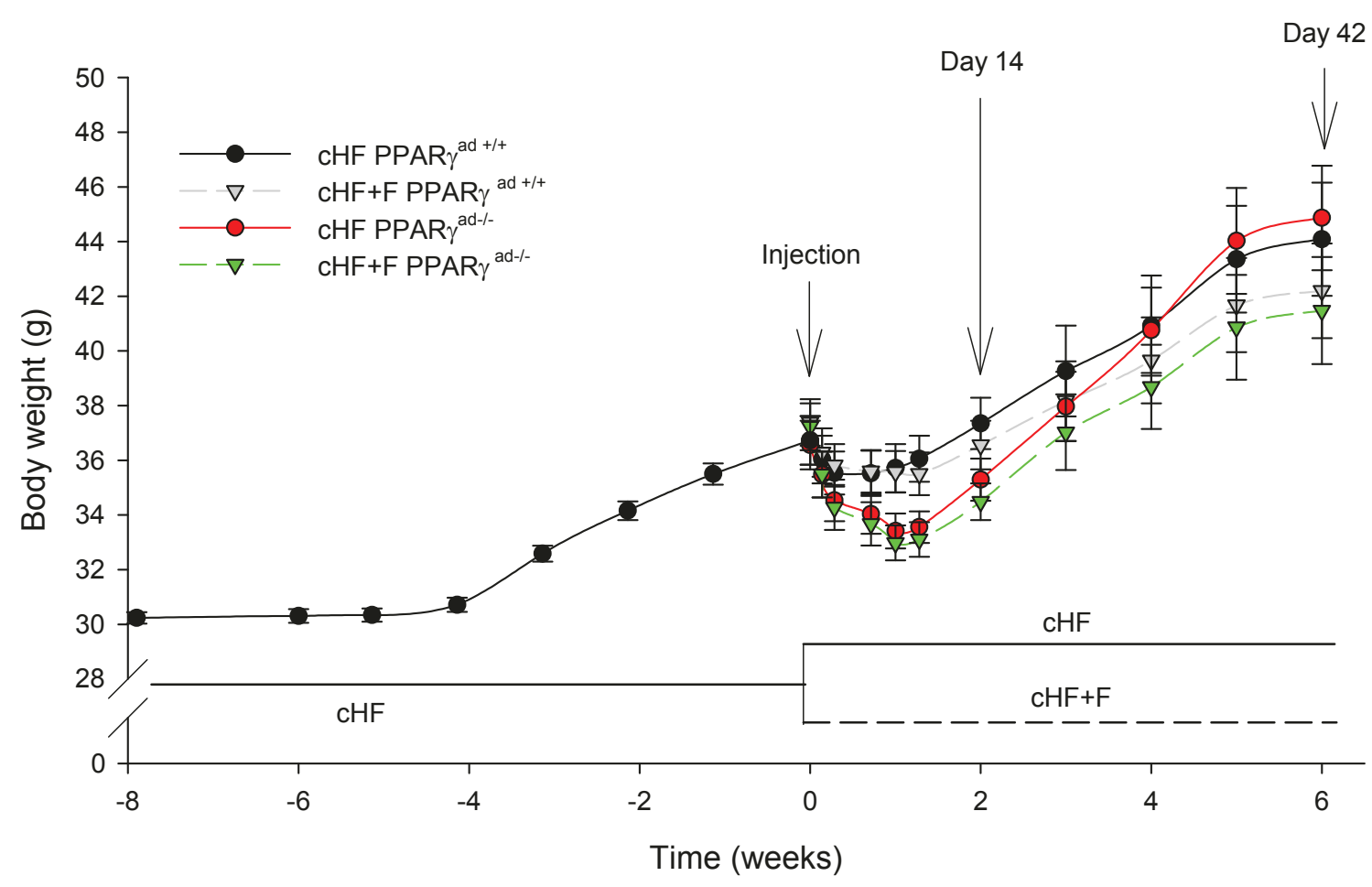

B

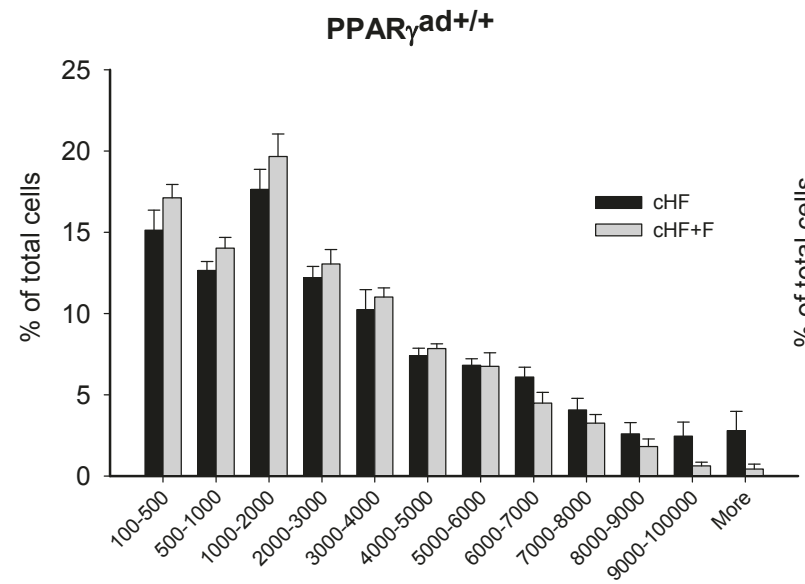

Cell surface area $\left(\mu \mathrm{m}^{2}\right)$

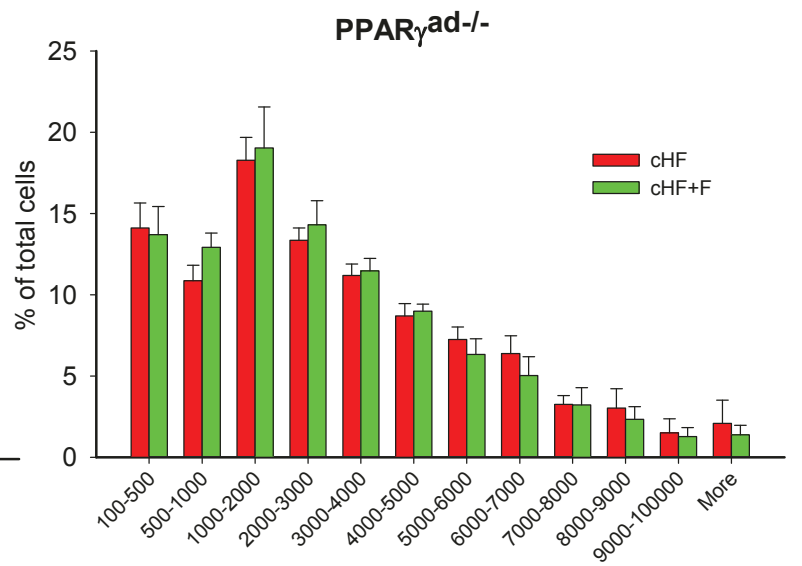

Cell surface area $\left(\mu \mathrm{m}^{2}\right)$

Figure 1 Growth characteristics. After 8 weeks of high-fat (CHF) feeding, mice were randomly assigned to one of the following groups: (i) control mice, fed CHF (CHF PPAR $\left.{ }^{\text {ad+/+ }}\right)$; (ii) mutant mice, fed CHF (CHF PPAR $\left.\gamma^{\text {ad- } /}\right)$; (iii) control mice, fed cHF enriched by LC $n-3$ PUFA (cHF $+F$ PPAR $\gamma^{\text {adt/+ }}$ ); and (iv) mutant mice, fed $c H F+F\left(C H F+F\right.$ PPAR $\gamma^{\text {ad- }-/}$ ). Part of mice were killed at day 14 , while the remaining mice were killed at day 42. A Body weights; B Frequency distribution of adipocyte cell surface area in epididymal fat at day 42 . Data are means $\pm S E ; n=10$. 
Table 1 Gene specific forward and reverse primer sequences used for qRT-PCR

\begin{tabular}{cccc}
\hline Gene & Forward primer & Reverse primer & NCBI accession number \\
\hline Cidec/Fsp27 & GACAAGCCCTTCTCCCTGGTG & CCATCAGAACAGCGCAAGAAGAGA & NM_178373.3 \\
Cox3 & TCATCGTCTCGGAAGTATTIT & CCACATAAATCAAGCCCTACTAAT & NC_005089.1 \\
Cyph $\beta^{*}$ & ACTACGGGCCTGGCTGGGTGAG & TCATCATTGTCGACTCCGGCA & NM_011149.2 \\
Eef2 ${ }^{*}$ & GAAACGCGCAGATGTCCAAAAGTC & CCTAGACTTGCAGCCCGGC & NM_007907.2 \\
Pgc- $\boldsymbol{\alpha} \alpha$ & CCCAAAGGATGCGCTCTCGTT & AATCAAGCCACTACAGACACCGCA & NM_008904.2 \\
Ppar $\alpha$ & TGCGCAGCTCGTACAGGTCATCAA & TAAGACTACCTGCTACCGAAATGGGGG & NM 011144.6 \\
Scd- 1 & ACTGGGGTGCTAATCTCTGGGTGTA & TAACAAACCCACCCCAGAGATAAAGCC & NM_009127.4 \\
\hline
\end{tabular}

Cidec/Fsp27 - cell death-inducing DFFA-like effector c; Cox3 - cytochrome c oxidase subunit III; Cyph $\beta$ - cyclophilin- $\beta$; Eef2 - eukaryotic translation elongation factor 2; Pgc-1 $\alpha$ - PPAR $\gamma$ coactivator $1 \alpha$; Ppar $\alpha$ - peroxisome proliferator-activated receptor $\alpha$; Scd-1 - stearoyl- Coenzyme A desaturase 1 ; ${ }^{*}$ reference gene.

ANOVA with Holm-Sidak posthoc test using SigmaStat 3.5 statistical software. Comparisons were judged to be significant at $\mathrm{p} \leq 0.05$.

\section{Results}

After 8 weeks of cHF feeding, obese mice (body weight $36.9 \pm 0.4 \mathrm{~g}$ ) were randomly assigned to one of the four experimental groups (day 0; see Methods and Figure 1). In accordance with the previous study on this transgenic model [10], temporary controlled PPAR $\gamma$ ablation caused a transient body weight loss reflecting changes in body fat content. Mutant PPAR$\gamma^{\text {ad-/- }}$ mice (i.e., mice injected by tamoxifen in corn oil) achieved a maximum weight loss within 10 days postinjection, independent of diet. Also control PPAR $\gamma^{\text {ad }}$ $+/+$ mice showed a small reduction of body weight, reflecting the stress associated with the corn oil (without tamoxifen) injection. Afterward, all mice started to gain body weight with a different dynamics in various groups. Thus, (i) the cHF mice gained body weight much faster than the $\mathrm{cHF}+\mathrm{F}$ mice, (ii) at 6 weeks after the injection, when body weights stabilized in a groupspecific manner, body weights of the cHF mice were bigger as compared with the $\mathrm{cHF}+\mathrm{F}$ mice; and (iii) the dissociation in final body weights in response to the presence/absence of LC $n-3$ PUFA in the diet was more apparent in the mutant as compared with the control mice. Therefore, the mutant mice showed the highest final body weights when fed cHF diet, and the highest reduction in body weight gain when fed $\mathrm{cHF}+\mathrm{F}$ diet (Figure $1 \mathrm{~A}$ and Table 2). In any period post-injection, food consumption was not affected by either dietary LC $n-3$ PUFA or genotype (not shown). The weights of interscapular brown fat, dorsolumbar subcutaneous and epididymal white fat were significantly reduced in mutant mice killed at day 14 (Table 2). At day 42 , there were no differences between control and mutant mice within same diets, while $\mathrm{cHF}+\mathrm{F}$ diet became the main force of reduction of adiposity. In accordance with its effect on body weight gain, the $\mathrm{cHF}+\mathrm{F}$ diet prevented white fat depot growths between day 14 and day 42 more effectively in the mutant as compared with control mice (Table 2).

Histological and morphometric analysis of epididymal fat was performed to characterize effect of PPAR $\gamma$ ablation on tissue morphology in the model of dietary obese mice. At day 14, mean size of adipocytes was smaller in mutant as compared with control mice, and it was decreased further in response to dietary LC $n-3$ PUFA, resulting in the smallest adipocytes in the $\mathrm{cHF}+\mathrm{F}$ mutant mice (Table 2). Importantly, at day 42, mean size of adipocytes was similar in all the groups (Table 2), and also distribution of fat cell sizes was not significantly affected by either diet, or the transient genetic ablation of PPAR $\gamma$ (Figure 1B).

Expression of selected genes was quantified in epididymal fat (Figure 2). At day 14, compared to cHF control mice, a marked down-regulation of $S c d-1$ was found in remaining groups. At day 42 , only dietary LC $n-3$ PUFA diminished $S c d-1$ expression independently on genotype. Genes connected to lipid metabolism, Pparo, Cox3 and Cidec (Fsp27), were transiently down-regulated in the mutant as compared with control mice at day 14 only. Dietary LC $n-3$ PUFA induced expression of these genes at both time points, with the strongest effects elicited in the mutant mice in response to the longer treatment.

Plasma levels of total adiponectin and of its biological active high molecular weight (HMW) form, which is implicated in enhancement of insulin sensitivity [12], were lower in mutant as compared with control mice at day 14. Latter on, total and HMW adiponectin level were similar in both control and mutant mice, with a tendency to be higher in the mutant mice (Table 2). In accordance with our previous findings showing induction of adiponectin by LC $n-3$ PUFA $[3,13]$, adiponectin levels were higher in the $\mathrm{cHF}+\mathrm{F}$ as compared with the cHF mice, in both control and mutant mice, even at day 14 (Table 2).

\section{Discussion}

Adipose tissue belongs to the most flexible tissues in the body, because it is rapidly remodeled by hyperplasia and 
Table 2 Body weight, fat depots weight, adipocyte size and plasma adiponectin

\begin{tabular}{|c|c|c|c|c|}
\hline & \multicolumn{2}{|c|}{ PPAR $^{\text {ad+/+ }}$} & \multicolumn{2}{|c|}{ PPAR $\gamma^{\text {ad-/- }}$} \\
\hline & $\mathrm{cHF}$ & $\mathrm{cHF}+\mathrm{F}$ & $\mathrm{cHF}$ & $\mathrm{cHF}+\mathrm{F}$ \\
\hline \multicolumn{5}{|c|}{ Final body weight (g) } \\
\hline Day 42 & $44.1 \pm 2.1$ & $42.2 \pm 1.8$ & $44.9 \pm 1.9$ & $41.5 \pm 2^{c}$ \\
\hline \multicolumn{5}{|c|}{ Epididymal fat (mg) } \\
\hline Day 14 & $1607 \pm 210$ & $1369 \pm 165$ & $1169 \pm 184^{\mathrm{a}}$ & $1180 \pm 28^{\mathrm{a}}$ \\
\hline Day 42 & $2934 \pm 292$ & $2391 \pm 191^{a}$ & $2892 \pm 354$ & $2378 \pm 261^{a, c}$ \\
\hline \multicolumn{5}{|c|}{ Size of adipocytes $\left(\mu \mathrm{m}^{2}\right)$} \\
\hline Day 14 & $4397 \pm 518$ & $3381 \pm 285^{\mathrm{a}}$ & $3471 \pm 422^{\mathrm{a}}$ & $3126 \pm 323^{a, b}$ \\
\hline Day 42 & $3232 \pm 267$ & $2653 \pm 139$ & $3182 \pm 323$ & $2964 \pm 273$ \\
\hline \multicolumn{5}{|c|}{ Subcutaneous fat (mg) } \\
\hline Day 14 & $479 \pm 59$ & $395 \pm 39$ & $319 \pm 37^{a}$ & $332 \pm 37^{a}$ \\
\hline Day 42 & $686 \pm 64$ & $542 \pm 59$ & $656 \pm 73$ & $463 \pm 74^{a, c}$ \\
\hline \multicolumn{5}{|c|}{ Interscapular brown fat (mg) } \\
\hline Day 14 & $147 \pm 17$ & $124 \pm 11$ & $123 \pm 13^{a}$ & $121 \pm 8^{a}$ \\
\hline Day 42 & $190 \pm 23$ & $159 \pm 13$ & $179 \pm 15$ & $150 \pm 3$ \\
\hline \multicolumn{5}{|c|}{ Adiponectin (A.U.) } \\
\hline \multicolumn{5}{|l|}{ Day 14} \\
\hline HMW & $0.70 \pm 0.06$ & $0.79 \pm 0.06$ & $0.52 \pm 0.03^{\mathrm{a}}$ & $0.50 \pm 0.04^{\mathrm{a}, \mathrm{b}}$ \\
\hline MMW & $0.79 \pm 0.04$ & $0.82 \pm 0.03$ & $0.51 \pm 0.04^{\mathrm{a}}$ & $0.57 \pm 0.02^{b}$ \\
\hline LMW & $0.01 \pm 0.00$ & $0.01 \pm 0.00$ & $0.01 \pm 0.00$ & $0.01 \pm 0.00$ \\
\hline Total & $1.49 \pm 0.10$ & $1.62 \pm 0.08$ & $1.04 \pm 0.06^{a . b}$ & $1.12 \pm 0.06^{a, b}$ \\
\hline \multicolumn{5}{|l|}{ Day 42} \\
\hline HMW & $0.54 \pm 0.04$ & $0.96 \pm 0.10^{a}$ & $0.66 \pm 0.07$ & $1.06 \pm 0.11^{\mathrm{a}, \mathrm{c}}$ \\
\hline MMW & $0.53 \pm 0.02$ & $0.66 \pm 0.05$ & $0.58 \pm 0.04$ & $0.75 \pm 0.05^{\mathrm{a}, \mathrm{c}}$ \\
\hline LMW & $0.01 \pm 0.0$ & $0.02 \pm 0.0$ & $0.02 \pm 0.0$ & $0.02 \pm 0.0$ \\
\hline Total & $1.09 \pm 0.06$ & $1.64 \pm 0.15^{\mathrm{a}}$ & $1.25 \pm 0.10$ & $1.82 \pm 0.14^{\mathrm{a}, \mathrm{c}}$ \\
\hline
\end{tabular}

A.U., arbitrary units; HMW, high molecular weight adiponectin; MMW, medium molecular weight adiponectin; LMW, low molecular weight adiponectin; data are means $\pm \mathrm{SE} ; \mathrm{n}=10 ; a, b, c$ - significant differences compared to cHF PPAR $\gamma^{\text {ad }+/+}, \mathrm{cHF}+\mathrm{F} \mathrm{PPAR} \gamma^{\text {ad }+/+}$ and $\mathrm{cHF}^{\mathrm{PPAR}} \gamma^{\text {ad }-/ \text {, }}$, respectively.

hypertrophy of adipocytes, depending on energy fluxes. Fat cell turnover might contribute to determination of adiposity [9]. However, the mechanisms, which are involved in setting the turnover and their links to energy balance, remain to be established. Enormous plasticity of adipose tissue was also documented by our results. In agreement with the first study on this transgenic model [10], as well as other model of reversible lipoatrophy [14], 6 weeks after tamoxifen injection, adipose tissue from mutant mice appeared histologically identical to untreated mice, indicating complete tissue regeneration. The global, robust return of fat mass was confirmed by progressive body weight gain, especially in mutant mice fed cHF. The death fat cells are replaced by newly differentiated adipocytes originated from endogenous preadipocytes. The histological changes of epididymal fat depot from mice fed cHF were mirrored by changes of transcript levels for genes encoding Scd-1, Cidec (FSP27), and Cox3. As already described, the above genes are activated during adipocyte differentiation and maturation [15-17]. Similarly, plasma level of adiponectin was associated with the reduction of fat mass in the mutant mice compared to controls at day 14. Thus, similarly as in the transgenic mice fed chow diet [10], also in the dietary obese mice studied here, the transgenically-induced lipoatrophy was fully reversible within approximately 6 weeks after the PPAR $\gamma$ ablation.

Based on our previous results suggesting that the antiobesity effect LC $n-3$ PUFA could be, at least in part, explained by the prevention of fat cell proliferation during high-fat diet-feeding, we have challenged both control and the transgenic mice by dietary LC $n-3$ PUFA. 


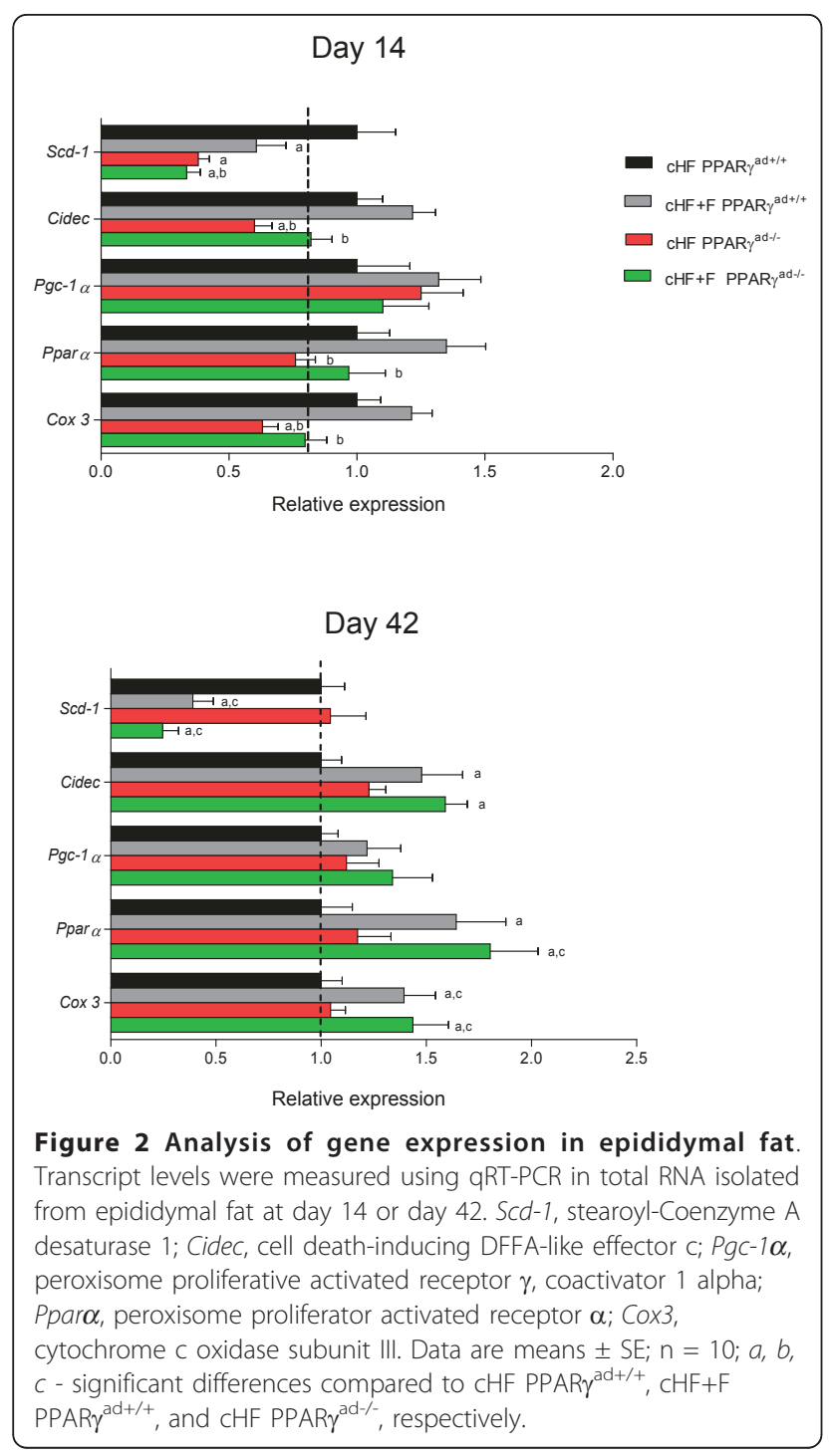

Indeed, the $\mathrm{cHF}+\mathrm{F}$ diet treatment decreased body weight gain in both control and mutant mice. At both time points analyzed (day 14 and day 42), total body weight, as well as weights of adipose depots were the lowest in the mutant mice fed $\mathrm{cHF}+\mathrm{F}$ diet. Nevertheless, when body weights stabilized in a group-specific manner, by the end of the treatment at 6 weeks, body weights were affected more by the diet than by the transient genetic ablation. Equal size of adipocytes in all the groups at the end of the treatment, suggest (i) similar number of adipocytes in epididymal fat within the same type of diet; (ii) existence of mechanisms, which tend to stabilize fat cell number via controlling fat cell turnover; and (iii) tuning of these hypothetical mechanisms by LC $n-3$ PUFA or their metabolites (see below).

In accordance with our already published data showing stimulation of mitochondrial biogenesis and $\beta$-oxidation [5] in white adipose tissue in response to dietary LC $n-3$ PUFA, feeding $\mathrm{cHF}+\mathrm{F}$ diet induced Pparo and Cox3 expression in control mice. At day 14, tamoxifen-induced-lipoatrophy in mutant mice was associated with lower expression of the above genes and interfered also with the LC $n-3$ PUFA effects. At day 42, expression of Ppar $\alpha$ and Cox 3 was strongly induced by dietary LC $n$ - 3 PUFA while no effect of tamoxifen injection was found. Furthermore, qRT-PCR analysis shown identical pattern of Cidec expression, i. e. significant reduction by tamoxifen treatment in control mice at day 14 and marked induction by LC $n-3$ PUFA at day 42 with the highest level in the mutant $\mathrm{cHF}+\mathrm{F}$ mice.

Our results document that dietary LC $n-3$ PUFA could decrease adiposity in obese mice by a mechanism, which depends on counteraction of both, differentiation and proliferation of adipose cells. One possible mechanism involves the changes in fatty acid composition of cellular membranes, and hence, altered formation of PUFAderived active metabolites like as eicosanoids $[1,6,18,19]$. The anti-proliferative effect may be involved in the decreased adiposity of pups born to rat dams that fed diets supplemented by $n-3$ fatty acids during gestation and sucking (reviewed in ref. [20]). It has been hypothesized that LC $n-3$ PUFA are involved in the anti-obesity effect of breast-feeding [21]. Importantly, our results support the notion [9] that adiposity is closely linked to the control of fat cell turnover and that mechanisms could exist, which control fat cell proliferation independent of energy balance.

\section{Abbreviations}

CHF: corn oil-based high fat diet; CHF+F: CHF diet supplemented with LC n-3 PUFA concentrate (15\% of dietary lipids); DHA: docosahexaenoic acid; EPA: eicosapentaenoic acid; PPAR-a $(-\gamma)$ : peroxisome proliferator activated receptor-a (- $\gamma)$; LC n-3 PUFA: long-chain $n-3$ polyunsaturated fatty acids.

\section{Acknowledgements}

This work was supported by the Czech Science Foundation (301/11/0226). $\mathrm{MH}$ was also supported by CSF PhD project (305/08/H037). The authors declare no conflict of interest.

\section{Author details}

${ }^{1}$ Department of Adipose Tissue Biology, Institute of Physiology Academy of Sciences of the Czech Republic v.vi.i, Prague, Czech Republic. ${ }^{2}$ Center for Integrative Genomics, National Research Center Frontiers in Genetics, University of Lausanne, Lausanne, Switzerland. ${ }^{3}$ Department of Functional Genomics, Institute of Genetics and Molecular and Cellular Biology, Illkirch, France.

\section{Authors' contributions}

$\mathrm{MH}$ performed the most of experiments and statistical analysis, contributed to writing of the manuscript; ZMJ and KB performed the histological analysis; WW, DM and PC created aP2-Cre-ER ${ }^{T 2}$ PPARY ${ }^{12 / L 2}$ transgenic murine model, participated in coordination of the study and revising the manuscript; JK participated in the design and coordination of the study and contributed to writing of the manuscript; DM and PC participated in the design and coordination of the study; PF performed initial animal experiments, participated in design and coordination of the study and 
drafted the manuscript. All authors read and approved the final version of the manuscript.

\section{Competing interests}

The author declares that they have no competing interests.

Received: 21 June 2011 Accepted: 2 August 2011

Published: 2 August 2011

\section{References}

1. Flachs P, Rossmeisl M, Bryhn M, Kopecky J: Cellular and molecular effects of $n-3$ polyunsaturated fatty acids on adipose tissue biology and metabolism. Clinical Sciences 2009, 116:1-16.

2. Ruzickova J, Rossmeisl M, Prazak T, Flachs P, Sponarova J, Vecka M, Trrzicka E, Bryhn M, Kopecky J: Omega-3 PUFA of marine origin limit dietinduced obesity in mice by reducing cellularity of adipose tissue. Lipids 2004, 39:1177-1185.

3. Jelenik T, Rossmeis M, Kuda O, Jilkova ZM, Medrikova D, Kus V, Hensler M, Janovska P, Miksik I, Baranowski M, Gorski J, Hebrand S, Jensen TE, Flachs P, Hawley S, Viollet B, Kopecky J: AMP-activated protein kinase a2 subunit is required for the preservation of hepatic insulin sensitivity by $n-3$ polyunsaturated fatty acids. Diabetes 2010, 59:2737-2746.

4. Kopecky J, Rossmeisl M, Flachs P, Kuda O, Brauner P, Jilkova Z, Stankova B, Tvrzicka E, Bryhn M: n-3 PUFA: bioavailability and modulation of adipose tissue function. Proc Nutr Soc 2009, 68:361-369.

5. Flachs $P$, Horakova $O$, Brauner $P$, Rossmeisl M, Pecina P, Franssen-van Hal NL, Ruzickova J, Sponarova J, Drahota Z, Vlcek C, Keijer J, Houstek J, Kopecky J: Polyunsaturated fatty acids of marine origin upregulate mitochondrial biogenesis and induce beta-oxidation in white fat. Diabetologia 2005, 48:2365-2375.

6. Danesch U, Weber PC, Sellmayer A: Differential effects of $n-6$ and $n-3$ polyunsaturated fatty acids on cell growth and early gene expression in Swiss 3T3 fibroblasts. J Cell Physiol 1996, 168:618-624.

7. Kim HK, Della-Fera M, Lin J, Baile CA: Docosahexaenoic acid inhibits adipocyte differentiation and induces apoptosis in 3T3-L1 preadipocytes. J Nutr 2006, 136:2965-2969.

8. Manickam E, Sinclair AJ, Cameron-Smith D: Suppressive actions of eicosapentaenoic acid on lipid droplet formation in 3T3-L1 adipocytes. Lipids Health Dis 2010, 9:57.

9. Spalding KL, Arner E, Westermark PO, Bernard S, Buchholz BA, Bergmann O, Blomqvist L, Hoffstedt J, Naslund E, Britton T, Concha H, Hassan M, Ryden M, Frisen J, Arner P: Dynamics of fat cell turnover in humans. Nature 2008, 453:783-787.

10. Imai T, Takakuwa R, Marchand S, Dentz E, Bornert JM, Messaddeq N, Wendling O, Mark M, Desvergne B, Wahli W, Chambon P, Metzger D: Peroxisome proliferator-activated receptor gamma is required in mature white and brown adipocytes for their survival in the mouse. Proc Natl Acad Sci USA 2004, 101:4543-4547.

11. Medrikova D, Macek JZ, Bardova K, Janovska P, Rossmeisl M, Kopecky J: Sex differences during the course of diet-induced obesity in mice: adipose tissue expandability and glycemic control. Int J Obes.

12. Kuda O, Jelenik T, Jilkova Z, Flachs P, Rossmeisl M, Hensler M, Kazdova L, Ogston N, Baranowski M, Gorski J, Janovska P, Kus V, Polak J, MohamedAli V, Burcelin R, Cinti S, Bryhn M, Kopecky J: n-3 Fatty acids and rosiglitazone improve insulin sensitivity through additive stimulatory effects on muscle glycogen synthesis in mice fed a high-fat diet. Diabetologia 2009, 52:941-951.

13. Flachs P, Mohamed-Ali V, Horakova O, Rossmeisl M, Hosseinzadeh-Attar MJ, Hensler M, Ruzickova J, Kopecky J: Polyunsaturated fatty acids of marine origin induce adiponectin in mice fed high-fat diet. Diabetologia 2006, 49:394-397.

14. Pajvani UB, Trujillo ME, Combs TP, lyengar $P$, Jelicks L, Roth KA, Kitsis RN, Scherer PE: Fat apoptosis through targeted activation of caspase 8: a new mouse model of inducible and reversible lipoatrophy. Nat Med 2005, 11:797-803.

15. Kim YC, Gomez FE, Fox BG, Ntambi JM: Differential regulation of the stearoyl-CoA desaturase genes by thiazolidinediones in 3T3-L1 adipocytes. J Lipid Res 2000, 41:1310-1316.

16. Nishino N, Tamori Y, Tateya S, Kawaguchi T, Shibakusa T, Mizunoya W, Inoue K, Kitazawa R, Kitazawa S, Matsuki Y, Hiramatsu R, Masubuchi S, Omachi A, Kimura K, Saito M, Amo T, Ohta S, Yamaguchi T, Osumi T,
Cheng J, Fujimoto T, Nakao H, Nakao K, Aiba A, Okamura H, Fushiki T, Kasuga M: FSP27 contributes to efficient energy storage in murine white adipocytes by promoting the formation of unilocular lipid droplets. $J$ Clin Invest 2008, 118:2808-2821.

17. Wilson-Fritch L, Burkart A, Bell G, Mendelson K, Leszyk J, Nicoloro S, Czech M, Corvera S: Mitochondrial biogenesis and remodeling during adipogenesis and in response to the insulin sensitizer rosiglitazone. $\mathrm{Mol}$ Cell Biol 2003, 23:1085-1094.

18. Madsen L, Petersen RK, Kristiansen K: Regulation of adipocyte differentiation and function by polyunsaturated fatty acids. Biochim Biophys Acta 2005, 1740:266-286.

19. Flachs P, Ruhl R, Hensler M, Janovská P, Zouhar P, Kus V, Macek JZ, Papp E, Kuda O, Svobodova M, Rossmeisl M, Tsenov G, Mohamed-Ali V, Kopecky J: Synergistic induction of lipid catabolism and anti-inflammatory lipids in white fat of dietary obese mice in response to calorie restriction and $n-3$ fatty acids. Diabetologia

20. Ailhaud G, Massiera F, Weill P, Legrand P, Alessandri JM, Guesnet P: Temporal changes in dietary fats: role of $n-6$ polyunsaturated fatty acids in excessive adipose tissue development and relationship to obesity. Prog Lipid Res 2006, 45:203-236.

21. Arenz S, Ruckerl R, Koletzko B, Von Kries R: Breast-feeding and childhood obesity-a systematic review. Int J Obes Relat Metab Disord 2004, 28:1247-1256.

\section{doi:10.1186/1476-511X-10-128}

Cite this article as: Hensler et al:: The inhibition of fat cell proliferation by $n-3$ fatty acids in dietary obese mice. Lipids in Health and Disease 2011 10:128.

\section{Submit your next manuscript to BioMed Central and take full advantage of:}

- Convenient online submission

- Thorough peer review

- No space constraints or color figure charges

- Immediate publication on acceptance

- Inclusion in PubMed, CAS, Scopus and Google Scholar

- Research which is freely available for redistribution

Submit your manuscript at www.biomedcentral.com/submit
C Biomed Central 